\title{
Perspectives on global competitiveness in terms of modern challenges and threats: the case of leading world's economies for Ukraine"
}

\author{
Viktorita Y. ShKola ${ }^{i}$, Marrna D. Domashenko ${ }^{i i}$, Mrkola D. Vavilichev ${ }^{i i i}$
}

The purpose of the research is to study the global competitiveness of world's economies and the factors influencing, given the modern challenges faced and far-looking threats.

The competitiveness of the national economy has been found to involve the country's ability to compete with others through efficient use of available natural, physical, and intellectual capital to secure resilience and sustainability of nation in sort-term, medium-term and long-term period. The research is focused on analyses of indicators of global competitiveness of world's economies and the factors influencing, given the modern challenges faced and far-looking threats. The evaluation and comparison of the competitiveness of Ukraine and the highest performing countries according to the world rating on the base of the GCI and the WCR - 10 countries - Denmark, Germany, Hong Kong SAR, Japan, the Netherlands, Singapore, Sweden, Switzerland, the UAE, the USA - has been fulfilled. Strengths and weaknesses were evaluated by the method of mutual comparison. The main threats and challenges at the global and national levels are described. Consistent indicators of the leading counties' economies in context of far-looking global risks and national challenges are scrutinized. The study uses a mixed approach, including factorial analysis and descriptive statistics. Index method developed on the base of 'distance to frontier' approach applied to the countries' index ranking transformed into upward indices, is suggested to use. Future studies may explore the opportunities for optimization of national competitive advantages given global challenges, constant monitoring of the latest trends in the world economy and analysis of the impact of globalization processes on the formation of the country's competitiveness.

Keywords: economy, global competitiveness, threats, challenges, global risks, world competitiveness, global competitiveness index.

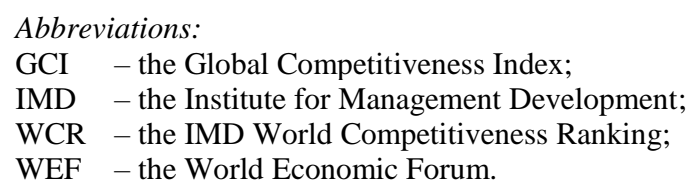

Introduction. Health and economic crises, faced by nations in 2019-2020, exposed that the issues of formation and maintenance of economies competitiveness and social resilience are crucial. The rapid development of advanced technologies brings competition to a new innovative level, and the deepening of integration and cooperation requires the states and

${ }^{i}$ Viktoriia Y. Shkola, C.Sc. (Economics), Associate Professor, Department of International Economic Relations, Sumy State University;

ii Maryna D. Domashenko, C.Sc. (Economics), Associate Professor, Department of International Economic Relations, Sumy State University;

${ }^{i i i}$ Mykola D. Vavilichev, student, Sumy State University.

* The article came into being within the Grant no. 0120U102003 entitled 'Process of formation of the novel ecologically safe fertilizers with prolonged action based on the phosphorite deposits raw material' financed by Ministry of Science and Education of Ukraine.

(C) V. Y. Shkola, M. D. Domashenko, M. D. Vavilichev, 2021.

https://doi.org/10.21272/mer.2021.92.06 
governments to increase economic security and protect the nations from modern challenges faced and threats foreseen. Readiness of the economy to respond and counteract challenges and threats is a very important indicator on the way to improvement welfare of the nation and the power of the economy as a whole. The latest global trends are likely to bring inescapable changes into world economic system that formed recent 20 years [20].

Problem statement. The fundamentals of economy competitiveness has been scrutinized by Ukrainian and foreign scholars, in particular, Alsaleh, M., \& Abdul-Rahim, A. S. [1], de Miranda, R. L., dos Santos, L. F. I., Gomes, G. \& Parisotto, I. R. D. [2], Galgankova, V. [3], Kálmán, B. \& Tóth, A. [16], Poliakova, Ju [21], Porter, M. [22] etc. Study of the potential for growth of global economic competitiveness given the national index of intellectual capital has been carried out in works [24-26]. However, the current challenges and forward-looking threats for people and the planet in conjunction with the newly discovered contradictory trends in globalization require rethinking of the concept of competitiveness nationally, exploring key components of economy's resilience, and sustainability as part of the global macrosystem.

The purpose of the research is to study the global competitiveness of world's economies and the factors influencing, given the modern challenges faced and far-looking threats.

Results of the research. Generally, the country's international competitiveness is considered as an ability of the country to create such a national business environment in a free and fair market where domestic producers can constantly develop their competitive advantages, occupy, and form stable positions in certain segments of the world market, owing to its innovative capabilities, affordability of intellectual capital, and investment resources, the flexibility of response to changing word's environment. It should be noted, that currently economic environment is increasingly uncertain, challenging and complex, thereby growth and recovery remains vulnerable to a range of risks, potential shocks and crises [31].

The fact that competitiveness is the main category of a market economy is undisputed. Since the world's environment is changing, the meaning of this term itself is being improved, expanded, and supplemented. The founder of the nations' competitiveness theory M. Porter interprets it as a constant support of productivity at a higher level than competitors, through advanced innovative development [22]. According to M. Porter theory, the state's ability to provide its citizens with a sufficiently high and growing standard of living depends on productivity of national resources use, namely labor and capital. This approach formed the basis of the well-known production concept of competitiveness of the national economy [22].

Meanwhile, J. Sachs focused on global competitiveness as "the set of institutions and economic policies supporting high rates of economic growth in the medium term" [27]. The object of competitiveness at the national level has been argued to be no longer the goods of individual firms, but instead the conditions of social production. Hence, the competitiveness of the national economy is a prerequisite and tool for country's sustainable economic development [23]. In this context, terms of "competitiveness" and "productivity" are suggested to use interchangeably [31].

Moreover, within the latter concept "GDP per capita" indicator instead of "Productivity of labor" is used optionally. It should be noted, that such an approach is wider than aforesaid one, because it depends on the total factor productivity. In particular, the WEF defines competitiveness as the country's ability to achieve consistently high GDP growth rates per capita.

Furthermore, global competitiveness is regarded as "the set of institutions, policies, and factors that determine the level of country's productivity and, consequently, the level of economy's prosperity. It should be noted, there are bilateral interdepend able relations 
Viktoriia Y. Shkola, Maryna D. Domashenko, Mykola D. Vavilichev. Perspectives on global competitiveness in terms of modern challenges and threats: the case of leading world's economies for Ukraine

between the level of economy's productivity and the investments rates of return. Being the determinant of the investments rates of return, the level of economy's productivity depends on them in turn. In other words, the key indicator of competitive economy is thought to be a pace of economy growth (growth rate) over time. Thus, the competitiveness concept encompasses both static and dynamic components of country's productivity. The former derives from the ability to sustain a high level of income, whereas the latter results from return on investment, driving economy's growth capabilities [28].

Accelerating the market fluctuations with political and social changes have helped modernize the concept of national competitiveness from maintaining a competitive position in the world market and thus ensuring the country's prosperity to its ability to adapt quickly to innovations, tackle challenges and threats. This is a potentially new approach that is conditionally opposed to all other concepts. However, it most accurately corresponds to modern conditions, when the primacy of goods and services is not material component, but intellectual one. Therefore, giving the definition of the concept of nation's competitiveness were taken as a basis of innovative potential of the country, supplementing it with key elements taken from each concept.

Analyzing the general trends of the concept and highlighting its main features, the competitiveness of the national economy has been found to involve the country's ability to compete with others through efficient use of available natural, physical, and intellectual capital to secure resilience and sustainability of nation in sort-term, medium-term, and longterm period. What is the vital is the fact that within this approach "competitiveness is not a zero-sum game between countries - it is achievable for all countries" [31].

The concept of global competitiveness is increasingly being used to assess the state and maturity of country, its economic growth and productivity. The latter means a country's ability to maintain a high level of income, but it is also one of the main factors influencing the return on investment that reflects the growth potential of the specific economy [30].

Comparative analyses of nation's competitiveness has been carried out on the base of selected the GCI from 2016 to 2020 [29-33] and the WCR from 2016 to 2021 [4-15]. The figures were obtained on the basis of the WCR published annually and subsequently processed into a chart and a table.

Not only does it allow the countries to analyze, but also make a comparative assessment of methods and indices. In addition, the study allows us to conclude on the following key areas:

- areas, a country should prioritize

- country's progress over time

- the experience of the highest performing countries, a country should learn from.

Assessment of competitive positions of Ukraine in world ratings is shown in tables 1-4, compiled on the data of the GCI, provided by the WEF, and the WCR, provided by IMD. Given the results of world's countries ranking during 2016-2021, the highest ranking countries, taken rank from $1^{\text {st }}$ up to $5^{\text {th }}$ have been defined as leading ones.

The top 5 leading countries for 2017-2019 according to WEF are shown in table 1. Owing to the fact that the methodology of GCI calculation was changed in 2018, for alignment of data the results have been analyzed for periods provided by the data available for comparison.

According to the GCI provided by the WEF [30-32] the top 5 best-performing countries over 2017-2019 are Germany, Hong Kong SAR, Japan, the Netherlands, Singapore, Switzerland, the USA, taken the rank from $1^{\text {st }}$ to $5^{\text {th }}$ during aforesaid period (Table 1).

The top 5 leading countries for 2016-2021 according to IMD are shown in tables 2-3. According to the WCR provided by IMD [4-13] the top 5 best-performing countries over 
В. Ю. Школа, М. Д. Домашенко, М. Д. Вавілічев.

Перспективи глобальної конкурентоспроможності

в умовах сучасних викликів та загроз: приклад провідних економік світу для України

2016-2021 are Denmark, Hong Kong SAR, the Netherlands, Singapore, Sweden, Switzerland, the UAE, the USA, taken the rank from $1^{\text {st }}$ to $5^{\text {th }}$ during aforesaid period.

Top 5 leading countries for 2017-2019 and Ukraine by the WEF

Table 1

(own elaboration based on [29-31])

\begin{tabular}{|l|c|c|c|c|c|c|}
\hline \multirow{3}{*}{ Country } & \multicolumn{6}{|c|}{ The GCI 4.0** } \\
\cline { 2 - 7 } & $2017 / 135^{* *}$ & $2018 / 140^{* * *}$ & \multicolumn{2}{c|}{$2019 / 141$} \\
\cline { 2 - 7 } & Score & Rank & Score & Rank & Score & Rank \\
\hline Germany & 82,6 & 3 & 82,8 & 3 & 81,8 & 7 \\
\hline Hong Kong SAR & 82 & 7 & 82,3 & 7 & 83,1 & 3 \\
\hline Japan & 81,6 & 8 & 82,5 & 5 & 82.3 & 6 \\
\hline Netherlands & 82,2 & 5 & 82,4 & 6 & 82,4 & 4 \\
\hline Singapore & 83 & 2 & 85,6 & 2 & 84,8 & 1 \\
\hline Switzerland & 82,4 & 4 & 82,6 & 4 & 82,3 & 5 \\
\hline United States & 84,8 & 1 & 83,5 & 1 & 83,7 & 2 \\
\hline Ukraine & 53,9 & 89 & 57 & 83 & 57 & 85 \\
\hline
\end{tabular}

${ }^{*}$ Up to 2017 scores measured on a 1-to-7 scale (the GCI methodology), since 2018 scores measured on a 0 -to-100 scale (the GCI 4.0 methodology);

${ }^{* *}$ the indicators are converted to 0 -to-100 scale in order to align them with further the GCI 4.0 results calculated using the GCI 4.0 methodology;

${ }^{* * *}$ in the table $-\ldots / 140$ - indicator of the number of countries.

Table 2

Top 5 leading countries for 2016-2021 and Ukraine overview in 2021 (by IMD) (own elaboration based on [4-13])

\begin{tabular}{|c|c|c|c|c|c|c|c|c|c|}
\hline Indicator & 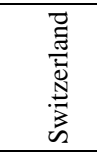 & $\begin{array}{l}\text { D̃ } \\
\frac{0}{0} \\
\vdots \\
\text { n }\end{array}$ & 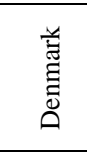 & 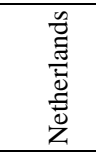 & 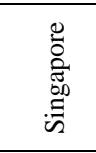 & $\begin{array}{l}00 \\
0 \\
0 \\
0 \\
0 \\
0 \\
0 \\
0 \\
0\end{array}$ & 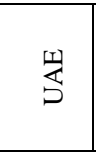 & 㤅 & 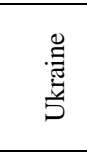 \\
\hline \multicolumn{10}{|c|}{ Basic Facts } \\
\hline Land area (km2 '000) & 41 & 447 & 43 & 42 & 1 & 1 & 71 & 9,832 & 604 \\
\hline Exchange Rate (Per \$) & 0.939 & 9.210 & 6.542 & 0.876 & 1.380 & 7.757 & 3.673 & 1.000 & 26.958 \\
\hline Population (million) & 8.61 & 10.38 & 5.82 & 17.41 & 5.69 & 7.48 & 9.28 & 330.09 & 41.58 \\
\hline GDP ( $\$$ billion $)$ & 747.5 & 537.6 & 355.2 & 912.5 & 340.0 & 349.4 & 358.9 & $20,934.9$ & 155.6 \\
\hline GDP (PPP) per capita $(\$)$ & 72,874 & 54,148 & 58,93 & 57,533 & 98,527 & 59,458 & 70,117 & 63,416 & 13,080 \\
\hline Real GDP growth (\%) & -3.0 & -2.8 & -2.7 & -3.7 & -5.4 & -6.1 & -6.1 & -3.5 & -4.0 \\
\hline Consumer price inflation $(\%)$ & -0.73 & 0.66 & 0.33 & 1.12 & -0.18 & 0.33 & -2.07 & 1.25 & 2.74 \\
\hline Unemployment rate $(\%)$ & 4.82 & 8.29 & 5.80 & 4.80 & 3.00 & 5.80 & 4.25 & 8.09 & 9.50 \\
\hline Labor force (million) & 4.93 & 5.52 & 2.92 & 9.34 & 3.71 & 3.89 & 7.26 & 160.74 & 17.67 \\
\hline Current account balance, $\%$ & 3.81 & 5.24 & 7.81 & 7.78 & 17.59 & 6.61 & 5.85 & -3.09 & 4.00 \\
\hline \multicolumn{10}{|c|}{ Direct Investment } \\
\hline Stocks inward ( $\$$ billion) & $1,350.7$ & 339.5 & 105.7 & $1,749.8$ & $1,697.6$ & $1,867.9$ & 154.1 & $9,465.8$ & 48.9 \\
\hline Flows inward (\% of GDP) & 5.10 & 3.13 & -2.14 & 3.93 & 32.17 & 15.94 & 4.28 & 1.64 & 3.79 \\
\hline
\end{tabular}

It should be noted that results of the world rankings, provided by the WEF and IMD, are likely to be different. Comparative analysis of the results is shown in table 4.

Likelihood of the complete coincidence is estimated to be less than $15 \%$. It might be explained by the difference of methodologies and indices. 
Viktoriia Y. Shkola, Maryna D. Domashenko, Mykola D. Vavilichev. Perspectives on global competitiveness in terms of modern challenges and threats: the case of leading world's economies for Ukraine

Table 3

The WCR in 2021 of top 5 leading countries for 2016-2021 and Ukraine (by IMD) (own elaboration based on [4-13])

\begin{tabular}{|c|c|c|c|c|c|c|c|c|c|c|}
\hline \multicolumn{2}{|c|}{ Country/Rank in 2021} & 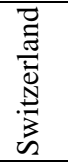 & $\begin{array}{l}\frac{5}{0} \\
\frac{d}{3} \\
\text { is }\end{array}$ & 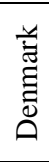 & 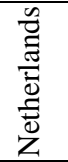 & 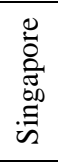 & 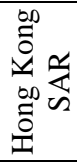 & $\underset{\square}{\square}$ & $\begin{array}{l}\mathbb{L} \\
\stackrel{2}{D}\end{array}$ & $\frac{\stackrel{\oplus}{\Xi}}{\stackrel{\Xi}{\Xi}}$ \\
\hline \multicolumn{2}{|c|}{ Overall performance (64 countries) } & 1 & 2 & 3 & 4 & 5 & 7 & 9 & 10 & 54 \\
\hline \multirow{5}{*}{ 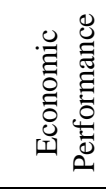 } & Domestic Economy & 4 & 10 & 12 & 16 & 15 & 32 & 20 & 2 & 57 \\
\hline & International trade & 15 & 17 & 10 & 3 & 1 & 2 & 4 & 34 & 38 \\
\hline & International investment & 12 & 17 & 24 & 4 & 3 & 7 & 19 & 2 & 56 \\
\hline & Employment & 15 & 30 & 22 & 4 & 18 & 40 & 39 & 29 & 49 \\
\hline & Prices & 58 & 41 & 42 & 48 & 57 & 63 & 10 & 49 & 43 \\
\hline \multirow{5}{*}{ 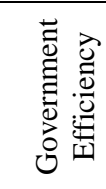 } & Public Finance & 1 & 7 & 5 & 10 & 12 & 9 & 3 & 56 & 52 \\
\hline & Tax Policy & 12 & 58 & 56 & 60 & 8 & 2 & 3 & 15 & 24 \\
\hline & Institutional Framework & 1 & 3 & 5 & 4 & 7 & 11 & 13 & 18 & 59 \\
\hline & Business Legislation & 10 & 4 & 2 & 7 & 3 & 1 & 5 & 19 & 55 \\
\hline & Societal Framework & 5 & 4 & 3 & 6 & 17 & 34 & 15 & 42 & 48 \\
\hline \multirow{5}{*}{ 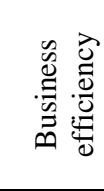 } & Productivity \& Efficiency & 4 & 3 & 1 & 8 & 14 & 9 & 16 & 7 & 54 \\
\hline & Labour Market & 6 & 5 & 14 & 2 & 4 & 8 & 1 & 28 & 38 \\
\hline & Finance & 1 & 6 & 7 & 4 & 13 & 3 & 25 & 2 & 64 \\
\hline & Management Practices & 9 & 3 & 1 & 15 & 14 & 2 & 8 & 6 & 43 \\
\hline & Attitudes and Values & 13 & 4 & 6 & 2 & 9 & 8 & 1 & 25 & 34 \\
\hline \multirow{5}{*}{ 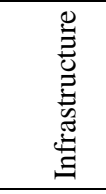 } & Basic Infrastructure & 5 & 10 & 3 & 6 & 20 & 7 & 21 & 16 & 52 \\
\hline & Technological Infrastructure & 8 & 3 & 6 & 2 & 1 & 7 & 18 & 5 & 51 \\
\hline & Scientific Infrastructure & 3 & 7 & 11 & 13 & 17 & 23 & 33 & 1 & 49 \\
\hline & Health and Environment & 3 & 1 & 4 & 16 & 25 & 21 & 36 & 17 & 61 \\
\hline & Education & 1 & 4 & 3 & 12 & 7 & 8 & 31 & 13 & 40 \\
\hline
\end{tabular}

As far as the WCR is concerned, the methodology is based on 334 competitiveness criteria encompassed 4 pillars, namely economic performance, government efficiency, infrastructure, and business efficiency. The criteria are revised and updated on a regular basis as new theory, research and data become available and as the global economy evolves. Generally, the WCR measures the prosperity and competitiveness of 64 countries by comprehensive research using economic literature, international, national and regional sources and feedback from the business community, government agencies and academics [4].

Meanwhile, the GCI 4.0 methodology is intent to assess a total of 103 indicators (against 98 in 2018) organized into 12 pillars, namely Institutions; Infrastructure; ICT adoption; Macroeconomic stability; Health; Skills; Product market; Labour market; Financial system; Market size; Business dynamism; and Innovation capability. Data for the GCI are expected to derive from international organizations and the WES's Executive Opinion Survey. In general, the GCI reflects the extent and complexity of the drivers of productivity and the competitiveness ecosystem of 141 countries (in 2019) [31-32].

For a detailed analysis of the factors of competitiveness, it is proposed to use the economies' graphic competitiveness profile (fig. 1-3), formed on the basis of the author's methodology. The profile is suggested to draw on the basis of the countries' index ranking transformed into upward indices. By a 'distance to frontier' approach, performance on each 
В. Ю. Школа, М. Д. Домашенко, М. Д. Вавілічев.

Перспективи глобальної конкурентоспроможності

в умовах сучасних викликів та загроз: приклад провідних економік світу для України

component is evaluated against the 'frontier', or ideal state. Analysis of countries' profiles is intended to estimate the distance to the frontier in a given area and use the experience of those who are performing best in selected areas.

The world rankings of countries by the WCI and the CGI*

Table 4 (own elaboration based on [4-15, 29-33])

\begin{tabular}{|c|c|c|c|c|c|c|c|c|c|c|c|c|}
\hline \multirow{3}{*}{ Country } & \multicolumn{12}{|c|}{ The world rankings } \\
\hline & \multicolumn{2}{|c|}{2016} & \multicolumn{2}{|c|}{2017} & \multicolumn{2}{|c|}{2018} & \multicolumn{2}{|c|}{2019} & \multicolumn{2}{|c|}{2020} & \multicolumn{2}{|c|}{2021} \\
\hline & WCI & GCI & WCI & GCI** & WCI & GCI & WCI & GCI & WCI & GCI & WCI & $\mathrm{GCI}$ \\
\hline Denmark & 6 & 12 & 7 & 11 & 6 & 10 & 8 & 10 & 2 & $\mathrm{n} / \mathrm{a}$ & 3 & $\mathrm{n} / \mathrm{a}$ \\
\hline Germany & 12 & 4 & 13 & 3 & 15 & 3 & 17 & 7 & 17 & $\mathrm{n} / \mathrm{a}$ & 15 & $\mathrm{n} / \mathrm{a}$ \\
\hline Hong Kong SAR & 1 & 7 & 1 & 7 & 2 & 7 & 2 & 3 & 5 & $\mathrm{n} / \mathrm{a}$ & 7 & $\mathrm{n} / \mathrm{a}$ \\
\hline Japan & 26 & 6 & 26 & 8 & 25 & 5 & 30 & 6 & 34 & $\mathrm{n} / \mathrm{a}$ & 31 & $\mathrm{n} / \mathrm{a}$ \\
\hline Netherlands & 8 & 5 & 5 & 5 & 4 & 6 & 6 & 4 & 4 & $\mathrm{n} / \mathrm{a}$ & 4 & $\mathrm{n} / \mathrm{a}$ \\
\hline Singapore & 4 & 2 & 3 & 2 & 3 & 2 & 1 & 1 & 1 & $\mathrm{n} / \mathrm{a}$ & 5 & $\mathrm{n} / \mathrm{a}$ \\
\hline Sweden & 5 & 9 & 9 & 9 & 9 & 9 & 9 & 8 & 6 & $\mathrm{n} / \mathrm{a}$ & 2 & $\mathrm{n} / \mathrm{a}$ \\
\hline Switzerland & 2 & 1 & 2 & 4 & 5 & 4 & 4 & 5 & 3 & $\mathrm{n} / \mathrm{a}$ & 1 & $\mathrm{n} / \mathrm{a}$ \\
\hline UAE & 15 & 17 & 10 & 27 & 7 & 27 & 5 & 25 & 9 & $\mathrm{n} / \mathrm{a}$ & 9 & $\mathrm{n} / \mathrm{a}$ \\
\hline United States & 3 & 3 & 4 & 1 & 1 & 1 & 3 & 2 & 10 & $\mathrm{n} / \mathrm{a}$ & 10 & $\mathrm{n} / \mathrm{a}$ \\
\hline Ukraine $* * *$ & 59 & 85 & 60 & 89 & 59 & 83 & 54 & 85 & 55 & $\mathrm{n} / \mathrm{a}$ & 54 & $\mathrm{n} / \mathrm{a}$ \\
\hline The number of countries & 61 & 138 & 63 & 135 & 63 & 140 & 63 & 141 & 63 & $\mathrm{n} / \mathrm{a}$ & 64 & $\mathrm{n} / \mathrm{a}$ \\
\hline
\end{tabular}

$\square$ - large divergence $\square$ - moderate divergence

- low divergence

- complete coincidence $\square$ - no data available for comparison

${ }^{*}$ Up to 2017 scores measured on a 1-to-7 scale (the GCI methodology), since 2018 scores measured on a 0 -to-100 scale (the GCI 4.0 methodology);

** the indicators are converted to 0 -to-100 scale in order to align them with further the GCI 4.0 results calculated using the GCI 4.0 methodology;

${ }^{* * *}$ So as to compare the results, the authors' methodology has been proposed to use.

As governments, businesses and societies survey the damage inflicted over the last year, strengthening strategic foresight is now more important than ever. According to the Global Risk Report 2021 [34], published by the WEF, key global threats of the next decade are cyberattacks, weapons of mass destruction and, most notably, climate change. Among the highest likelihood risks of the next ten years are extreme weather, climate action failure and human-led environmental damage; as well as digital power concentration, digital inequality and cybersecurity failure. Among the highest impact risks of the next decade, infectious diseases are in the top spot, followed by climate action failure and otherenvironmental risks; as well as weapons of mass destruction, livelihood crises, debt crises and IT infrastructure breakdown. Only if are appropriate measures taken globally, existing and future challenges will be overcome successfully. It should be noted that the threat and challenges assessment nationally highlights some of those connections as it provides the national authorities' baseline assessments of the most pressing threats to national interests, while emphasizing the economy's key adversaries and competitors. It is not an exhaustive assessment of all global challenges and notably excludes assessments of country adversaries' vulnerabilities [17-19]. 
Viktoriia Y. Shkola, Maryna D. Domashenko, Mykola D. Vavilichev. Perspectives on global competitiveness in terms of modern challenges and threats: the case of leading world's economies for Ukraine

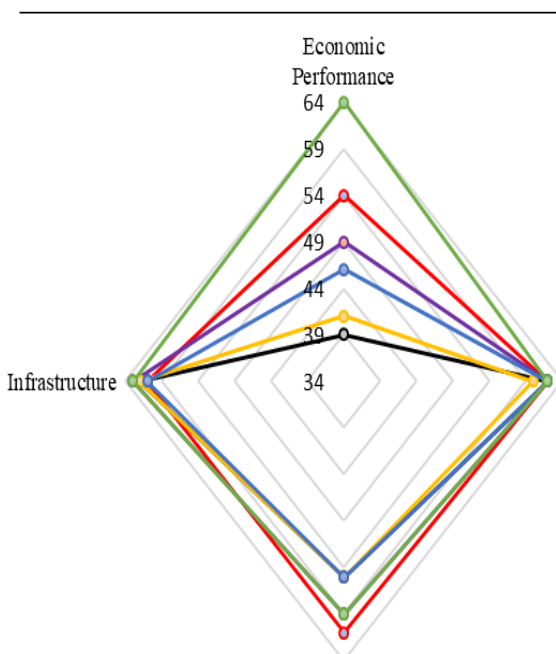

Business Efficiency

$\rightarrow 2016 \rightarrow 2017 \rightarrow 2018 \rightarrow 2019 \rightarrow 2020$

a) Switzerland

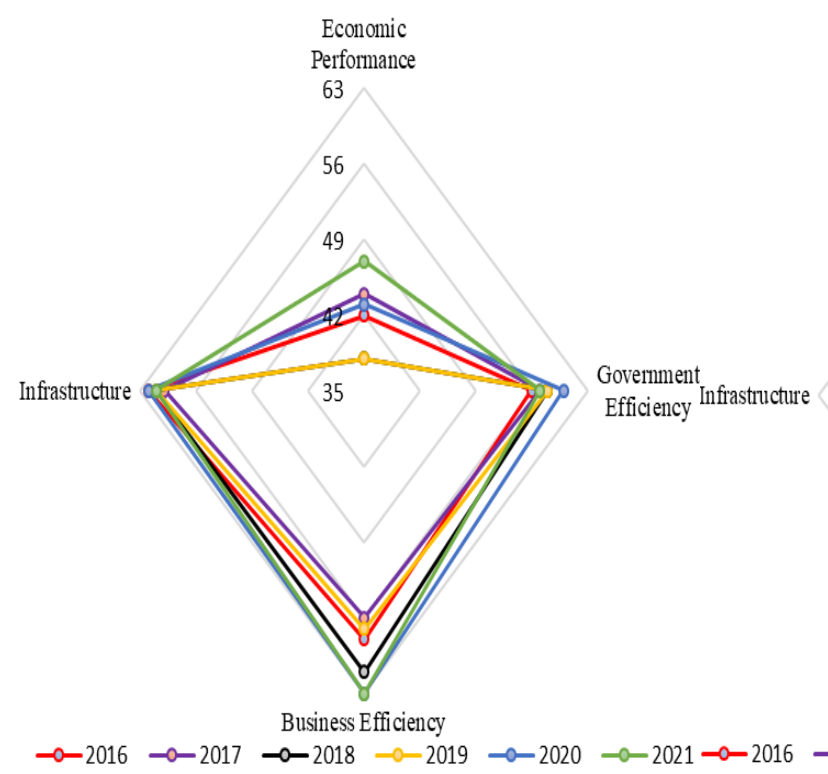

c) Denmark

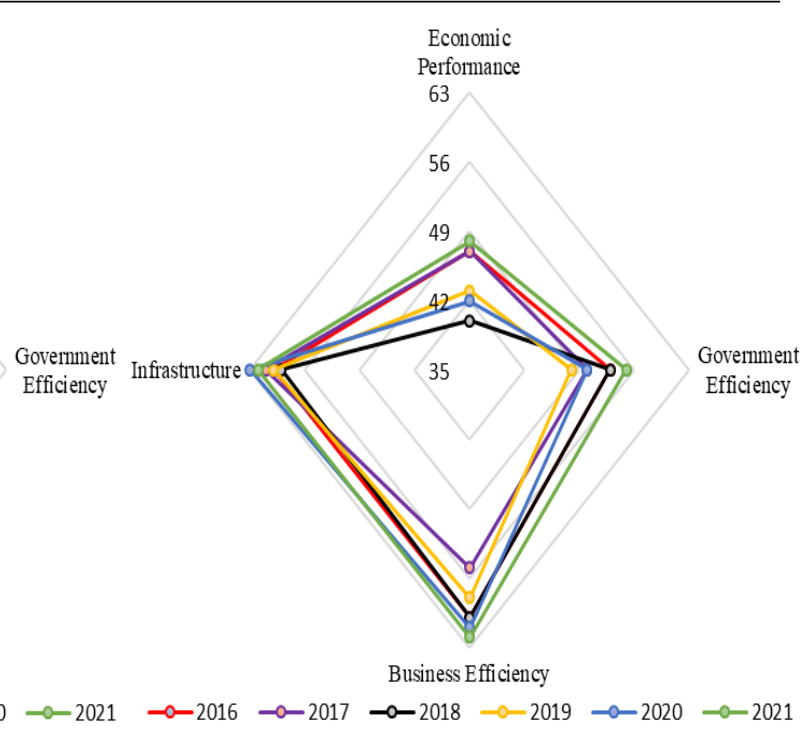

b) Sweden

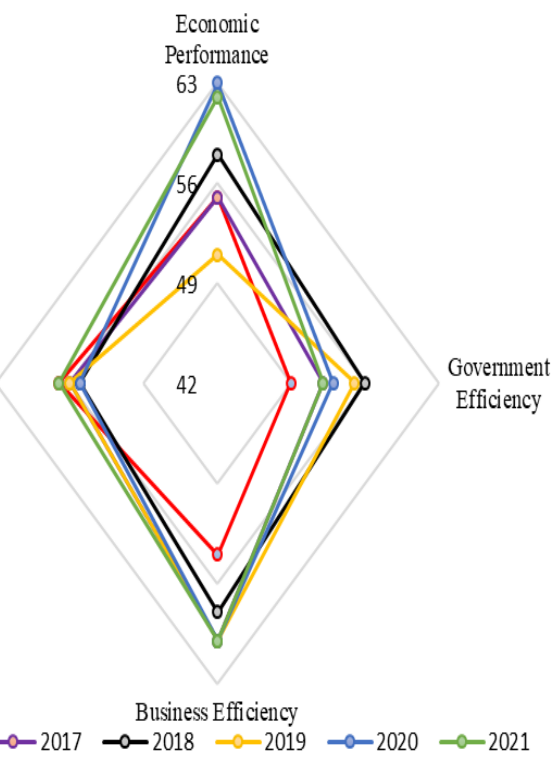

d) The Netherlands

Figure 1. Global competitiveness profile of economies:

a) Switzerland, b) Sweden, c) Denmark, d) The Netherlands (own elaboration based on [4, 6-9]) 
В. Ю. Школа, М. Д. Домашенко, М. Д. Вавілічев.

Перспективи глобальної конкурентоспроможності

в умовах сучасних викликів та загроз: приклад провідних економік світу для України

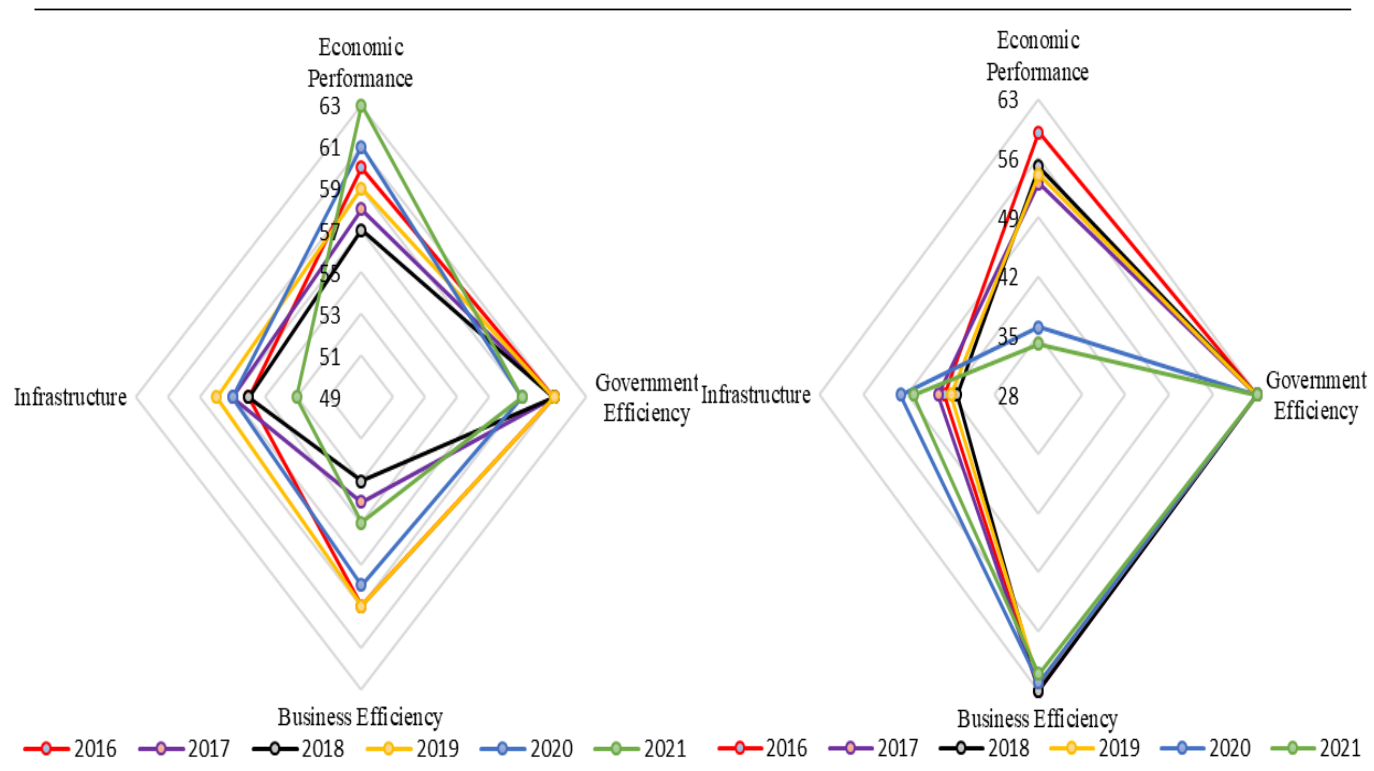

a) Singapore

b) Hong Kong SAR

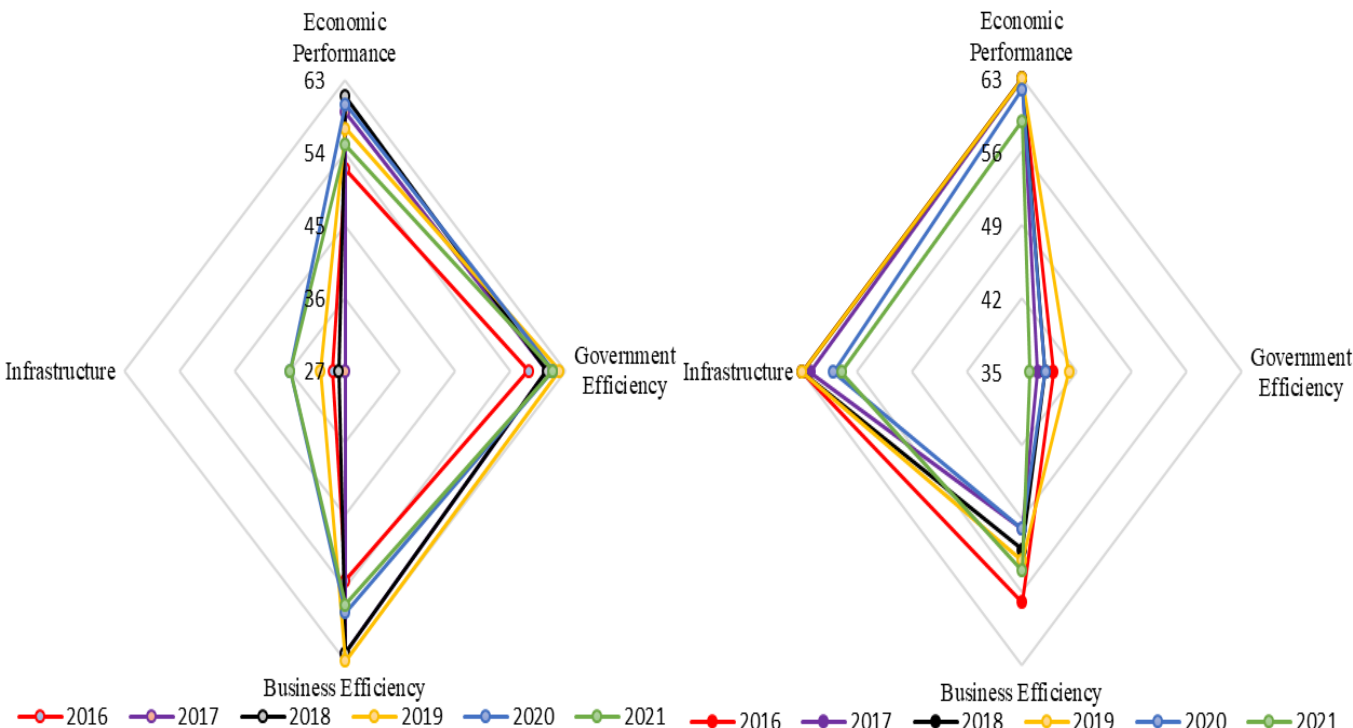

c) the UAE

d) the USA

Figure 2. Global competitiveness profile of economies:

a) Singapore, b) Hong Kong SAR, c) the UAE, d) the USA (own elaboration based on [4, 10-13]) 
Viktoriia Y. Shkola, Maryna D. Domashenko, Mykola D. Vavilichev. Perspectives on global competitiveness in terms of modern challenges and threats: the case of leading world's economies for Ukraine

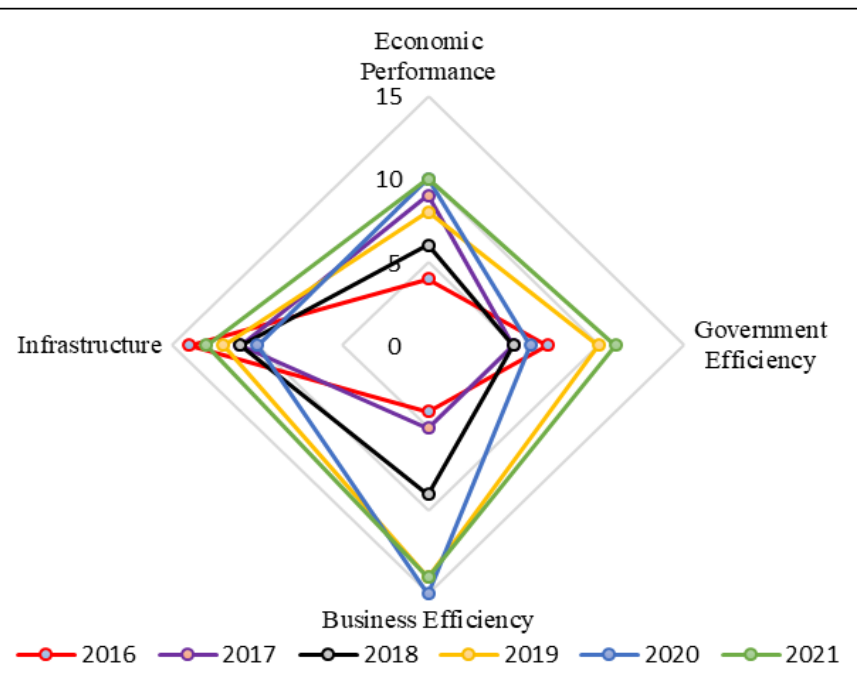

Figure 3. Global competitiveness profile of Ukraine's economy (own elaboration based on $[4,5]$ )

According to analysis of SECO - State Secretariat for Economic Affairs, in 2021 challenges for Switzerland are the following:

- taking over Covid-19 pandemic and ensuring a rapid economic recovery;

- preventing protectionism and markets openness;

- strengthening competition in domestic sectors so as to increase productivity;

- adjustment and cushion structural change and preserve financial stability in the challenging monetary environment;

- increasing sustainability of social welfare and pension systems [6].

According to analysis of Confederation of Danish Industry, in 2021 challenges for Denmark are likely to be the following:

- aid of the Danish companies negatively affected by the health and economic crisis resulted from COVID-19;

- support of companies so as to expand the export scale;

- securing better access to skilled labor; skills;

- productivity growth by means of boosting investments in ICT, automation and digital

- enhancing growth and accelerating the green transition by means of fiscal policy [8].

According to Confederation of Netherlands Industry and Employers (VNO-NCW) (the Hague), in 2021 challenges for the Netherlands is expected to be the following:

- maximal accelerating safety reopen the economy by means of broad access to coronavirus vaccines;

- creating recovery plan focused on three key issues, namely decreasing companies debt, motivating to invest (preferably in key enabling technologies), and preventing taxes growth for coming years;

- collaboration between government and private business on investing;

- gradually achieving national consensus on measures to meet Sustainable development goals; 
В. Ю. Школа, М. Д. Домашенко, М. Д. Вавілічев.

Перспективи глобальної конкурентоспроможності

в умовах сучасних викликів та загроз: приклад провідних економік світу для України

- incentivizing creation of vital infrastructure and housing by means of solving legal obstacles [9].

Economics Division of Ministry of Trade and Industry of Singapore, challenges are expected to be tackled in 2021 are the following:

- support for businesses transformation and capturing growth opportunities while changing the global economic landscape;

- by developing skills and abilities of workers, expanding labor capabilities to secure jobs in growth sectors;

- preserving companies' core capabilities suffered from the coronavirus pandemic [10].

According to Hong Kong Trade Development Council, in 2021 challenges for Hong Kong SAR are the following:

- navigating through an external environment amidst resurrected unilateralism and protectionism, and increasing macroeconomic vulnerability;

- use of growth opportunities deriving from the Mainland's new development strategy of "dual circulation", in particular the Belt and Road Initiative and Greater Bay Area development;

- boosting and accelerating innovative development as driver of long-term economic growth. and technology development as key driver for long-term economic growth.

- trying to solve problem of development constraints of inadequate land supply and an ageing population [11].

According to Federal Competitiveness \& Statistics Authority (FCSA) in Dubai, in 2021 the UAE Authorities intend to tackle the following challenges:

- coming up with place standardized guidelines owing to steady changes resulted from coronavirus pandemic;

- bankruptcy of businesses because of disturbed supply chains and impacted quality;

- going on the acceleration of regulatory and legislative reforms so as to adapt to post COVID-19;

- developing constantly the government's economic diversification agenda [12].

According to report, provided by Intelligence Community (in particular, Office of the Director of National Intelligence) [19], the most direct, serious threats to the United States during 2021 are the following:

- China increasingly becoming a near-peer competitor in multiple arenas, particularly in economy, military, and technology, and intending to shift global norms;

- Russian provocative measures, globally employing techniques up to and including the use of force;

- Iranian provocative measures and destabilizing activities regionally;

- North Korean provocative aggressive measures and potentially destabilizing activities to reshape the regional security environment and drive wedges between the United States and its allies;

- International and Domestic terrorism;

- functional concerns, such as weapons of mass destruction and technology, deriving from actors, such as China and Russia.

According to International Management Institute (MIM-Kyiv), in 2021 challenges for Ukraine are expected to be the following:

- dealing with coronavirus epidemic and securing widespread vaccination;

- boosting sanctions imposed on Russian Federation for Crimea occupation and failure to comply with the Minsk agreements; 
Viktoriia Y. Shkola, Maryna D. Domashenko, Mykola D. Vavilichev. Perspectives on global competitiveness in terms of modern challenges and threats: the case of leading world's economies for Ukraine

- strengthening the international coalition against Russian Federation, waged the hybrid Russian-Ukrainian war;

- facilitation of economic recovery and development of the private-public partnerships, especially for infrastructure projects;

- launching full-scale energy and land market;

- development of the domestic stock market and accumulation of pension system [5].

Unfortunately, it should be noted that unfavorable external challenges (first of all, the hybrid Russian-Ukrainian war), the spread and deepening of internal confrontations between leading political forces, the weakness of anti-corruption measures and a global pandemic have not yet allowed Ukraine to become a model of transformational reforms, to establish itself as a modern competitive country.

The new challenges as Covid-19 pandemic doesn't let to avoid a stage of periodical crises. Although each of the crisis periods had its own characteristics, but most of them have common features:

- intensification of political tensions and political confrontations, leading to a change in the political "elite";

- a sharp decline (over 6\%) in real GDP (except in 2004), primarily in terms of industrial production;

- loss of investment (sharp reduction of investments in the structure of GDP);

- deterioration of the foreign economic sector - growth of trade deficits, loss of reserves, devaluation of the national currency, etc.

One of the most important factors that allows a country to maintain a sustainable level of balanced growth and development is the level of national savings (in the structure of GDP), which is determined by the share of household income that is not consumed (and therefore can potentially be a source of investment). It will be recalled that the low level of domestic savings, on the one hand, may worsen the banking system's capacity for economic stimulus, reduce investment and investment potential (already medium-term), on the other hand - lead to deterioration of the current account balance (imbalances). "Savings-investments", inset "Macroeconomic relationship of savings, investments and current account"), which in the short term requires expanding access to external borrowing resources with deterioration of the country's debt situation.

But here Ukraine's position is significantly threatened by a large share of the shadow economy. The difference in the processes of development of the shadow economy in Ukraine is that inside the country a shadow part of the economy was formed rapidly, on the basis of a sharp change in property relations and planned socio-economic relations in the market. The shadow acted as a protective reaction of business, and more - without the adaptation of legal and organizational and managerial support of transformation processes. However, in the shadow segment, according to official data after the crisis are from one third to $40 \%$ of GDP. Digitalization of relations between the shadow economy and the use of new financial technologies - ordering goods in foreign online stores, payment not through traditional payment banking systems and online receipt of parcels without payment of wholesale customs duties requires changes in approaches to contain these negative phenomena and government measures for quality effective de-shadowing, not just the development of programs to combat it. The modern shadow digital economy with the development of national and international economic relations and financial and economic technologies acquires new, increasingly threatening properties. Today, the digitalization of the shadow economy with a certain sequence, intensity and volume is manifested in all countries and will be a new "battlefield" in 
trade wars between the leading powers of the 2020s.

One of the key trends in the development of Ukrainian economy today is reaching a global level of meeting the demand for goods and services and gradually increasing its place in the global rankings. Areas of regional specialization are gradually becoming subjects of global competition. Accordingly, increasing the competitiveness of these regions becomes an important factor not only in the socio-economic development, but also in increasing its competitiveness in general.

Improving the institutional structure of the economy, spreading incentives for transparent and legal profitable economic activity should be the basis for deep de-shadowing of the Ukrainian economy. The potential for forced de-shadowing, which has occurred as a result of streamlining tax administration, abolishing benefits, reducing the differentiation of customs tariffs, allocation of budget expenditures, financial control measures, etc., is gradually being exhausted. Further involvement in the official economic turnover of funds that serve shadow economic operations, or exported abroad, requires the development of a special long-term policy of legalization of shadow capital of non-criminal origin with maximum preservation of positive technological, organizational, financial and human potential accumulated in this sector.

Conclusions and prospects of further research. Theoretical principles of the concept of economy's competitiveness, the factors and patterns of formation of the country's competitiveness in the world ranking are determined. The competitiveness of the country depends on the ability to innovate, modernize production and technological processes, adapting to changing environmental conditions. Moreover, an important aspect of competitiveness is the uniformity of the country's development. Hence, the driving forces of competition are innovations, technologies and human potential. Evaluation of methodological means for determining the economy's competitiveness lets summarize that the index method developed on the base of 'distance to frontier' approach applied to the countries' index ranking transformed into upward indices, is optimal to use. Prospects for further research in this area are the optimization of national competitive advantages under the influence of global challenges, constant monitoring of the latest trends in the world economy and analysis of the impact of globalization processes on the formation of the country's competitiveness.

\section{References}

1. Alsaleh, M., \& Abdul-Rahim, A. S. (2021). Do global competitiveness factors effects the industry sustainability practices? Evidence from European hydropower industry, Journal of Cleaner Production, 310, 127492. https://doi.org/10.1016/j.jclepro.2021.127492

2. Miranda, R. L., Santos, L. F. I., Gomes, G. \& Parisotto, I. R. S. (2021). Competitiveness influence on global innovation of nations: a cross-sectional analysis. Independent journal of management \& production, 12 (4), 964-978. https://doi.org/10.14807/ijmp.v12i4.1338

3. Galgankova, V. (2020). Competitiveness of V4 countries using the global competitiveness index. Globalization and its Socio-Economic Consequences 2019. SHS Web of Conferences, 74, 06007 Retrieved from https://www.shsconferences.org/articles/shsconf/pdf/2020/02/shsconf_glob2020_06007.pdf https://doi.org/10.1051/shsconf/20207406007

4. IMD (2020). World Competitiveness ranking 2020. Factors ranking. Retrieved from https://www.imd.org

5. IMD World Competitiveness online. (2021). Competitiveness Ranking Ukraine. Rank 2021. Retrieved from https://worldcompetitiveness.imd.org/countryprofile/UA/wcy

6. IMD World Competitiveness online. (2021). Competitiveness Ranking Switzerland. Rank 2021. Retrieved from https://worldcompetitiveness.imd.org/countryprofile/CH/wcy 
Viktoriia Y. Shkola, Maryna D. Domashenko, Mykola D. Vavilichev. Perspectives on global competitiveness in terms of modern challenges and threats: the case of leading world's economies for Ukraine

7. IMD World Competitiveness online. (2021). Competitiveness Ranking Sweden. Rank 2021. Retrieved from https://worldcompetitiveness.imd.org/countryprofile/SE/wcy

8. IMD World Competitiveness online. (2021). Competitiveness Ranking Denmark. Rank 2021. Retrieved from https://worldcompetitiveness.imd.org/countryprofile/DK/wcy

9. IMD World Competitiveness online. (2021). Competitiveness Ranking Netherlands. Rank 2021. Retrieved from https://worldcompetitiveness.imd.org/countryprofile/NL/wcy

10. IMD World Competitiveness online. (2021). Competitiveness Ranking Singapore. Rank 2021. Retrieved from https://worldcompetitiveness.imd.org/countryprofile/SG/wcy

11. IMD World Competitiveness online. (2021). Competitiveness Ranking Hong Kong SAR. Rank 2021. Retrieved from https://worldcompetitiveness.imd.org/countryprofile/HK/wcy

12. IMD World Competitiveness online. (2021). Competitiveness Ranking UAE. Rank 2021. Retrieved from https://worldcompetitiveness.imd.org/countryprofile/AE/wcy

13. IMD World Competitiveness online. (2021). Competitiveness Ranking USA. Rank 2021. Retrieved from https://worldcompetitiveness.imd.org/countryprofile/US/wcy

14. IMD World Competitiveness online. (2021). Competitiveness Ranking Germany. Rank 2021. Retrieved from https://worldcompetitiveness.imd.org/countryprofile/DE/wcy

15. IMD World Competitiveness online. (2021). Competitiveness Ranking Japan. Rank 2021. Retrieved from https://worldcompetitiveness.imd.org/countryprofile/JP/wcy

16. Kálmán, B. \& Tóth, A. (2021). Links between the economy competitiveness and logistics performance in the Visegrád Group countries: Empirical evidence for the years 20072018. Entrepreneurial Business and Economics Review,9 (3), 169-190. https://doi.org/10.15678/EBER.2021.090311

17. NATO. (2021, June 14). Brussels Summit Communiqué. Press Release, 086. Retrieved from https://www.nato.int/cps/en/natohq/news_185000.htm

18. National Security Council. (2021, June). National strategy for countering domestic terrorism. Retrieved from https://www.whitehouse.gov/wp-content/uploads/2021/06/National-Strategy-forCountering-Domestic-Terrorism.pdf

19. Office of the Director of National Intelligence. (2021, April 9). Annual Threat Assessment of the US Intelligence Community. Retrieved from https://www.dni.gov/files/ODNI/documents/assessments/ATA-2021-Unclassified-Report.pdf

20. Reynolds, O. (2021, February 16). The World's Top 5 Largest Economies in 2024. FocusEconomics. Retrieved from https://www.focus-economics.com/blog/the-largest-economies-in-the-world

21. Poliakova, Ju. V. (2019). Innovatsiini zasady pidvyshchennia konkurentospromozhnosti rehioniv Ukrainy v protsesi yevrointehratsii [Innovative Principles of Increasing the Competitiveness of Ukraine's Regions in the Process of European Integration]. Doctor's thesis., Lviv: DU "Instytut rehionalnykh doslidzhen imeni M. I. Dolishnoho NAN Ukrainy". [in Ukrainian].

22. Porter, M. E. (1985). Competitive advantage of nations: creating and sustaining superior performance. New York: Free Press; London: Collier Macmillan. Retrieved from http://dspace.vnbrims.org

23. Sachs, J. \& Warner, A. (August 1995). Economic Reform and the Process of Global Integration, Brookings Papers on Economic Activity, 1.

24. Shkola, V. Y., $\quad$ Troyan, M. Y., $\quad$ Domashenko, M. D. \& Vavilichev M. D. (2021). Global Competitiveness of the Economy and Intellectual Capital Index: Case of the EU Countries and Ukraine. Mechanism of Economic Regulation, 1, pp. 108-119. Retrieved from https://doi.org/10.21272/mer.2021.91.09

25. Shkola, V. \& Vavilichev, M. (2020). Competitiveness of Ukraine in modern international economic relations. Proceedings from III IRPC: Ekonomika, innovatyka ta suchasni biznes-tekhnolohii: aktualni problemy ta rozvytok - The third International Scientific and Practical Conference "Economics, innovation and modern business technologies: current issues and development" (pp. 70-74.). Sumy: SDPU.

26. Shkola, V. (2020). Advanced development and Intellectual capital: an Influential assessment. Proceedings of the International Scientific and Practical Conference: Socio-Economic Challenges 
В. Ю. Школа, М. Д. Домашенко, М. Д. Вавілічев.

Перспективи глобальної конкурентоспроможності

в умовах сучасних викликів та загроз: приклад провідних економік світу для України

(pp. 482-487). Sumy: Sumy State University.

27. World Economic Forum (2001). The Global Competitiveness Report 2001-2002. Retrieved from https://citeseerx.ist.psu.edu/viewdoc/download?doi=10.1.1.476.4940\&rep=rep1\&type=pdf

28. World Economic Forum (2014). The Global Competitiveness Report 2014-2015. Retrieved from http://www3.weforum.org/docs/WEF_GlobalCompetitivenessReport_2014-15.pdf

29. World Economic Forum (2016). The Global Competitiveness Report 2016-2017. Retrieved from http://www3.weforum.org/docs/GCR2016

30. World Economic Forum (2017). The Global Competitiveness Report 2017-2018. Retrieved from http://www3.weforum.org/docs/GCR2017-

2018/05FullReport/TheGlobalCompetitivenessReport2017\%E2\%80\%932018.pdf

31. World Economic Forum (2018). The Global Competitiveness Report 2018. Retrieved from http://www3.weforum.org/docs/GCR2018/05FullReport/TheGlobalCompetitivenessReport2018.pdf

32. World Economic Forum (2019). The Global Competitiveness Report 2019. Retrieved from http://www3.weforum.org/docs/WEF_TheGlobalCompetitivenessReport2019.pdf

33. World Economic Forum (2020). The Global Competitiveness Report 2020. Special Edition 2020. How Countries are Performing on the Road to Recovery. Retrieved from http://www3.weforum.org/docs/WEF_TheGlobalCompetitivenessReport2020.pdf

34. World Economic Forum (2021). Global Risk Report 2021. Retrieved from http://www3.weforum.org/docs/WEF_The_Global_Risks_Report_2021.pdf

Manuscript received 25 March 2021

Mechanism of Economic Regulation, 2021, No 2, 51-65

ISSN 1726-8699 (print)

Перспективи глобальної конкурентоспроможності в умовах сучасних викликів та загроз: приклад провідних економік світу для України

\title{
ВІктоРІя ЮРЇ̈внА ШКОЛА*, МАРИНА ДМИТРІвНА ДОМАШЕНКо ${ }^{* *}$ МикоЛА ДМИтРОВИч ВАВІЛІчЕВ***
}

\author{
* кандидат економічних наук, доиент, доиент кафедри міжнародних економічних відносин \\ Сумського державного університету, \\ вул. Р.-Корсакова, 2, м. Суми, 40007, Україна, \\ тел.:00-380-542-332223, e-mail:v.shkola@macro.sumdu.edu.ua \\ ** кандидат економічних наук, дочент, доцент кафедри міжнародних економічних відносин \\ Сумського державного університету, \\ вул. Р.-Корсакова, 2, м. Суми, 40007, Украӥна, \\ тел.:00-380-542-332223, e-mail: m.domashenko@macro.sumdu.edu.ua \\ **** студент Сумського державного університету, \\ вул. Р.-Корсакова, 2, м. Суми, 40007, Україна, \\ тел.:00-380-542-332223,e-mail: mykola.vavilichev@ukr.net
}

Визначено теоретичні основи концепції конкурентоспроможності економіки, фактори та закономірності формування конкурентоспроможності країни в світовому рейтингу. Дослідження зосереджено на аналізі показників глобальної конкурентоспроможності світових економік і факторів, що впливають на них 3 урахуванням сучасних викликів і перспективних загроз. Проведено оцінку та порівняння конкурентоспроможності України та країн, що мають найвищі показники згідно зі світовим рейтингом, складеним за показниками GCI i WCR, - 10 країн Данія, Німеччина, ОАР Гонконг, Японія, Нідерланди, Сінгапур, Швеція, Швейцарія, ОАЕ, США. 
Viktoriia Y. Shkola, Maryna D. Domashenko, Mykola D. Vavilichev. Perspectives on global competitiveness in terms of modern challenges and threats: the case of leading world's economies for Ukraine

Оцінка сильних і слабких сторін проводилась методом взаємного порівняння. Описано основні загрози і виклики на глобальному та національному рівнях. Досліджено відповідні показники економік провідних країн в контексті глобальних ризиків, визначених на довгострокову перспективу, і національних викликів. У дослідженні використовується змішаний підхід, що включає факторний аналіз і описову статистику. Пропонується застосовувати індексний метод, розроблений на основі підходу «відстань до кордону» стосовно до індексного ранжирування країн, трансформованому у висхідні індекси. У майбутніх дослідженнях можуть бути вивчені можливості оптимізації національних конкурентних переваг з урахуванням глобальних викликів, постійного моніторингу останніх тенденцій в світовій економіці і аналізу впливу процесів глобалізації на формування конкурентоспроможності країни.

Ключові слова: економіка, глобальна конкурентоспроможність, загрози, виклики, глобальні ризики, світова конкурентоспроможність, індекс глобальної конкурентоспроможності.

JEL Codes: F01,F20, O18, P51, R11

Tables: 4; Figures: 3; References: 34

Language of the article: English 